\title{
Fragments of a Late Modernity: José Angel Valente and Samuel Beckett
}

for John Kronik, in memoriam, "il miglior fabbro"

$\mathrm{W}$ HAT DOES IT MEAN to be a modernist poet at the end of the twentieth century? Perhaps no poet more clearly embodies the ethos of "late modernism" than José Angel Valente, whose final book, Fragmentos de un libro futuro, was published after his death in the final year of the millennium. This book is not only posthumous but also designed to be posthumous. According to its front flap, "José Angel Valente concibió una suerte de obra poética 'abierta', un libro que-como la parábola cervantina de Ginés de Pasamonte o la novela de Proust —no acabaría sino con la desaparición misma del autor" (José Angel Valente conceived of a sort of "open" poetic work, a book that, like the Cervantine parabole of Ginés de Pasamonte or Proust's novel, would not end until the author himself disappeared; my translation here and throughout). The book's futurity, then, lies beyond the lifespan of the poet. Yet, in relation to the avant-garde movements of the earlier part of the twentieth century, Valente's book is decidedly nostalgic rather than forward looking. Its predominant tone is elegiac. While steeped in the culture of modernity, it ultimately exemplifies an arrière-garde rather than an avant-garde spirit. Given Valente's pre-eminent position within the canon of late twentieth-century Spanish poetry, an examination of his work during the last two decades of his life can also reveal the degree to which the modernist aesthetic has maintained its vitality in the contemporary period.

This essay is divided into two relatively autonomous sections. The first defines Valente's late modernism in relation to that of a key precursor, Samuel Beckett, perhaps the prototypical late modernist writer. I might have chosen another comparable figure, such as Paul Celan, but, as it happens, I have addressed Celan's strong influence on Valente at length elsewhere (Mayhew). Valente's deep affinities with Beckett have yet to be explored in the critical literature, and the centenary commemoration of Beckett's birth in 1906 makes this an appropriate time to devote an article to the Irish writer. The second section addresses the question of Valente's late modernism in the context of contemporary Spanish culture, 
where the problem of "modernity" is of central importance. If Valente's literary modernism derives from a belated, Beckettian model (as demonstrated in the first half of the article), how then can it serve as a modernizing force within contemporary Spain?

\section{Valente and Beckett: Residual Modernism}

That Valente's poetics derive largely from modernism can hardly be disputed. His admiration for high modernist icons is self-evident. It is not at all the same thing, however, to be a modernist poet at the beginning and at the tail end of the twentieth century. The later work of Valente, produced from the late 1970s through his death in 2000, stands at several removes from the original period in which the "great moderns"- poets like Rilke, Pessoa, Jiménez, and Breton-were forging new styles. Valente's closest literary influences, I would argue, are writers who comprise a second wave of modernism. In historical terms, the classic period of literary modernism is the teens and twenties, when modernist writers like Joyce, Stevens, Kafka, and Woolf were active and the historical avant-garde was taking shape in movements like Futurism, Dada, and Surrealism. Late modernism, then, is a second wave of modernist writing arising after World War II and exemplified by such figures as Samuel Beckett, Maurice Blanchot, and Paul Celan —all greatly esteemed by Valente.

Born in 1929, Valente is somewhat younger than these post-war European writers: Beckett was born in 1906, Blanchot in 1907, Celan in 1920. (Late modern Latin American poets-for example, José Lezama Lima [born 1910] and Octavio Paz [born 1914] -also form part of Valente's pantheon, although his personal relations with Paz eventually became strained.) The birth dates of such canonical Moderns as Pound, Joyce, and Kafka, on the other hand, are clustered in the 1880 s. Valente's poetry of the 1950s and early 1960s bears the mark both of the social realism prevalent in Spain during that decade and the existentialist current exemplified by Jean-Paul Sartre and Beckett himself. If Valente's turn toward a more explicitly "late modernist" aesthetic first becomes wholly visible, perhaps, in the 1971 Treinta y siete fragmentos, his mature work of the 1980s and 1990s clearly exemplifies the minimalist late modern ethos and in fact influenced many younger poets writing in the "essentialist" style. It is in this later period that he takes an intransigent stand against the anti-modernist "poesía de la experiencia” of Luis García Montero.

One way of locating Valente in literary history is to see him as writing "after Beckett," that is, not only after the great moderns of the earlier part of the century, but also after the culmination and virtual "death" of modernism in the later texts of Samuel Beckett, who writes with an acute consciousness of being at the end, rather than the beginning, of the modern movement. As I demonstrate below, Beckett's evocation of the literary death of modernity resonates strongly in Valente's late and posthumous poetry. In addition, Valente also writes "after Beckett" in a more direct sense, rewriting Beckettian motifs in a minimalistic style resembling that of the Irish writer.

The presence of Beckett in the Spanish poet's work is implicit rather than 
explicit: he rarely mentions Beckett in either his poetry or his prose, and critics have not made much of their connection either. ${ }^{1}$ However, according to the Galician scholar and poet Claudio Rodríguez Fer, Valente was in fact a devoted reader of Beckett (personal correspondence). Moreover, Beckett helped to shape and define the European literary habitus of the entire second half of the twentieth century-a period coinciding almost exactly with Valente's life's work.

Although Beckett's influence was felt most immediately and directly in the theater-in the works of Harold Pinter, Fernando Arrabal, and a whole generation of post World War II playwrights on several continents-it has never been confined to a single genre. His novels and short-stories are as significant as his plays in this regard, and prose-works like The Lost Ones and Ill Seen Ill Said are closer to avant-garde poetry than to conventional fiction. Thus, while he wrote few "poems" in comparison to his work in other genres, it is safe to say that contemporary poets have been counted among his most assiduous readers.

Although it may be impossible to determine precisely how much Valente took directly from Beckett and how much he borrowed from the Zeitgeist that the author of Waiting for Godot helped to define, there are at least four main elements of Beckett's work that would have made him an indispensable figure for the Spanish poet: (1) A terminal vision of human existence, namely a vision that focuses on the very last stage of life, dilating it to the extreme and often fixing on the liminal state between life and death. In several works, Beckett envisions an afterlife that is almost indistinguishable from this liminal state. (2) An extremely inwardlooking consciousness in which social reality all but disappears and the only available resources are those within. Because the mind is impoverished, however, it is seemingly incapable of any "rich inner life" that would be the source of poetic vision. (3) A negative mysticism, in that, while Beckett's work makes constant allusion to theological and mystical concepts and texts, his mystical asceticism fails to lead to a transcendent vision of God. (4) A terminal and residual literary language, austere to the extreme-in short, a conception of literary art consonant with this ascetic vision of life and death.

It is virtually a commonplace to identify Beckett as "the last modernist," to borrow a phrase from the subtitle of a recent biography (Cronin). Taken together, the elements I have outlined above suggest an exaggeration-or a critical parody, perhaps-of certain elements associated with canonical high modernism. Literary autonomy turns into a residual, seemingly inarticulate solipsism. "Purity"the rigorous exclusion of "extra-literary" reality-becomes ascetic minimalism. The prophetic vision of Yeats or Rilke is only visible as a form of "negative theology." Nevertheless, critical interpretations of Beckett show-rightly or wrongly - a strong tendency to recuperate negativity in the service of positive value. In his apparent renunciation of all forms of beauty and transcendence, in his extreme askesis that seems to leave no room for positivity, critics are often able to

\footnotetext{
${ }^{1}$ Beckett's name appears once in Las palabras de la tribu, but only as one item on a fairly long list of names. Lopo makes note of a passing reference to Krapp's Last Tape in Valente's Galician poetry, collected in Cantigas de alén (Lopo 49). She does not, however, provide any further commentary. Nor, frankly, does this reference seem particularly significant; I would argue that Beckett's invisible presence in Valente's work is more significant than these few visible traces.
} 
find an ultimately transcendent impulse. Shira Wolosky notes, for example, that interpreters of Murphy tend to view its eponymous protagonist as an ascetic mystic in search of union with a divine consciousness. Wolosky herself counters this tendency in order to read the novel as a "counter or even antimystical" text (9495) and takes a stand against such recuperations generally. There is, indeed, some danger in a facile recuperation of negativity: sometimes Beckett's negativity is flatly negative, offering no promise of redemption. At the same time, however, it is difficult to conclude that all such recuperation is illegitimate. As Wolosky herself admits, the recuperation in Beckett is aesthetic, taking place in and through language:

Beckett's work, in denying self-denial and negating negativity, finally reemerges toward affirmation: first in the language it itself generates, and not only as a concession but as a positive realization. Its gestures toward reduction inevitably give way to reproductive and inventive energy. (132-33)

The path of askesis, the renunciation of pleasure, ultimately produces a literature of stark, exceptional beauty. A text like "neither," written in 1976 for the avant-garde American composer Morton Feldman, exemplifies the pleasures of Beckett's late style:

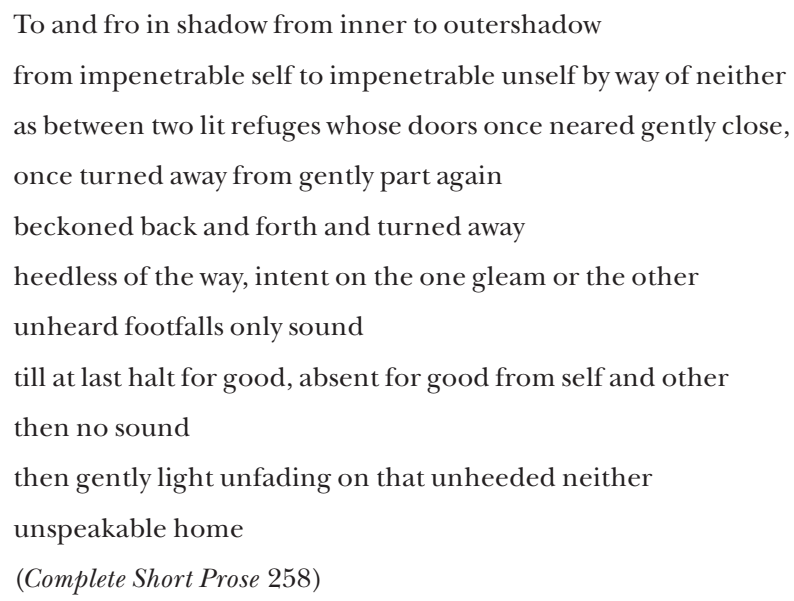

This text is liminal in several senses: standing between prose and poetry, it evokes a curious nether-land between life and death, subjectivity and the death of the subject. To interpret this text also brings into play a kind of second-order aporia, since this liminal state is presented as both hellishly frustrating and soothingly pleasant.

It is this later style of Beckett that is closest to Valente's own late poetry. Although Beckett is still best known for Waiting for Godot and for the mid-century "trilogy" of novels (Murphy, Malone Dies, The Unnameable), his later works are equally significant from a literary and poetic perspective. Boundaries between genres become less significant in the minimalistic, poetic prose of works like Fizzles and Worstword Ho. ${ }^{2}$ Beckett's late theater, by the same token, is often re-

${ }^{2}$ Although I cite titles of Beckett's work in English in this article, Beckett wrote mostly in French during his mature period, translating his own works into his native tongue. (Several important works, both early and late, were written first in English.) Valente would have read Beckett's work 
duced, with minimal staging, to a single actor speaking a prose text indistinguishable in style from a late Beckett "short-story." Thus it is not surprising that these works have had a greater impact on poets than on playwrights or writers of conventional prose fiction. Since Valente himself wrote some of his most significant poetry in short prose fragments, the difference between fiction and poetry becomes insignificant when considering the affinity between the two writers. ${ }^{3}$

Valente's elegiac "Paisaje con pájaros amarillos" (Landscape with Yellow Birds), written in memory of his son Antonio, evokes a mood very similar to that of Beckett's The Lost Ones, an extended description of an "Abode where lost bodies roam each searching for its lost one" (Complete Short Prose 202). Valente takes from Beckett, not the illusory precision of the geometric delineation, but the central motif of non-recognition. (In Beckett's hell, the dead are unable to find or recognize their loved ones.) Here is one of the longer fragments of Valente's sequence:

Tiento las sombras a la caída de la tarde, en la plenitud solar de la mañana, despierto o bien en sueños, y tal vez adelanto los brazos ante mí, palpo el ciego perfil que no consigo nombrar, creo que he visto seres que amo aún y que ya nunca volveré a ver o no me reconocerán ellos a mí, pues quién podría ahora reconocer a quién, cuando tú ya no estás y el último verano arrastró hacia lo lejos tus imágenes, muy lejos, y con ellas la sola referencia cierta a lo visible. (No amanece el cantor 107)

(I grasp the shadows at evening's fall, in the solar plenitude of morning, awake or else in dreams, and perhaps I reach out my arms ahead of me, I feel the blind profile that I am unable to name, I believe I have seen beings that I still love and that I will never again see or who would never recognize me, since who could recognize whom, when you're no longer here and the last summer dragged your images far, very far, and with them the only certain reference to the visible.)

Most, however, are much briefer:

Lentamente. Del otro lado. Yo apenas podía ahora oír tu voz. (65)

(Slowly. From the other side. I barely could hear now your voice.)

Al caer la tarde, la no visible mano de un dios te borra como ala de pájaro caído hacia qué densa sombra más allá de la sombra. Disuelto estás, al fin, en tu propia mirada. (87)

(As evening fell, the not visible hand of a god erases you like a wing of a bird fallen toward what dense shadow beyond shadow. You are dissolved, finally, in your own gaze.)

If Valente's lyric vision feels more intimately personal than Beckett's seemingly "objective" description of unrecognizable bodies in perpetual motion in The Lost Ones, we might recall that the elegiac mode in Beckett's work does find a much

mostly in French, I surmise, although his English was certainly up to the task. Valente lived and worked as a translator in Geneva (and in Beckett's Paris) for a good portion of his adult life and was steeped in French literary culture. On this topic see Lopo: "Nesta escritura o mundo francófono ocupa un lugar de preferencia; no só pola conexión directa e permenante de Valente coa lingua, por cuestións profesionais e de residencia, senón tamén pola vasta cultura francesa do poeta e polo seu profundo coñecemento de esta literatura" (41; In this writing the Francophone world occupies a privileged place, not only because of Valente's direct and permanent connection with the language, for professional and residential reasons, but also because of the poet's extensive acquaintance with French culture and deep knowledge of this literature).

${ }^{3}$ Gontarski makes a similar point: "Much of Beckett's short prose inhabits the margins between prose and poetry, between narrative and drama, and finally between completion and incompletion" (Beckett, The Complete Short Prose xiii). On the relation of Beckett's late prose to contemporary poetry, see Perloff's "Between Verse and Prose: Beckett and the New Poetry" (The Dance of the Intellect 135-54). 
more personal expression in such works as the late play Ohio Impromptu ( Collected Shorter Plays 283-88).

Although thematic and stylistic parallels between Becket and Valente are not difficult to find, the most significant connection between them occurs at the level of poetics. Beckett's aesthetics of retraction into the self, his insistence on negativity and passivity, find numerous echoes in Valente's work. Already in his 1931 essay on Proust, Beckett shows a marked preference for explorations of interior consciousness:

The only fertile research is excavatory, immersive, a contraction of the spirit, a descent. The artist is active, but negatively, shrinking from the nullity of extra-circumferential phenomena, drawn in to the core of the eddy. (Beckett, Proust 65-66)

Granted, this passage refers ostensibly to Marcel, the protagonist of Proust's multivolume novel, who in Beckett's reading is unable to find ultimate satisfaction in his friendships and must therefore ultimately choose a more solitary course. But it also serves as an apt premonition of Beckett's own explorations of "negative consciousness."

Valente, echoing Beckett's position, stresses interiority and a sort of receptive passivity:

Escribir es como la segregación de las resinas; no es un acto, sino lenta formación natural. Musgo, humedad, arcillas, limo, fenómenos de fondo, y no de sueño o de los sueños, sino de los barros oscuros donde las figuras de los sueños fermentan. Escribir no es hacer, sino aposentarse, estar. (Material memoria 115)

(Writing is like the secretion of resins; it is not an act, but a slow natural formation. Moss, dampness, clays, mud, phenomena of the depth, and not of sleep or dreams, but of the dark soils where the figures of dreams ferment. To write is not to act, but to settle, to be.)

In both Beckett and Valente, introspection leads to a kind of askesis in which writing becomes an account of the death of consciousness. Valente offers one version of this radical death of the subject in the last of the series of aphorisms entitled "A propósito del vacío, la forma y la quietud" (Concerning Emptiness, Form, and Quietude):

La escritura es lo que queda en las arenas, húmedas, fulgurantes todavía, después de la retirada del mar. Resto, residuo. Ejercicio primordial de no existencia, de autoextinción. (Notas de un simulador 31)

(Writing is what remains in the sands-humid, still shining, after the withdrawal of the sea. Remainder, residue. Primordial exercise of non-existence, of auto-extinction.)

Just as Valente identifies his writing as "Resto, residuo," so Beckett uses the rubric Residua for a collection of some of his shorter prose pieces. The idea of a kind of residual writing, a writing symbolically equivalent to the relics of a past civilization, is consonant with the elegiac mode of both writers. It could also be argued that late modernism is culturally "residual" in the sense that Raymond Williams gives this term (122). In other words, it is no longer the dominant literary movement, but a cultural formation of the past that remains imbedded in the social fabric.

While Valente's ascetic sensibility and austere minimalism is demonstrably indebted to Beckett, there are a few significant differences between the two writers that are relevant to the discussion of Valente as a "late modern." While Beckett might appear rather narrow, focused on a few obsessive motifs, Valente takes this 
tendency to an extreme, appearing even more ascetic and monochromatic, even more restricted in his repertory of motifs. The extremely brief, gnomic texts of "Paisaje con pájaros amarillos" thus could be seen as Beckettian texts executed on an even smaller scale. Valente's work also lacks the Irish writer's comic exuberance and narrative range.

If Valente pushes the late modernist style to an extreme of compression and brevity, it could also be said that in relation to the epoch in which he was writing he is a much less radical figure than the Irish writer. Beckett in his day was one of the most innovative writers in European literature, whereas Valente, in the 1980s and 1990s, was an arrière-garde figure, distilling the poetic insights of the late moderns rather than pushing beyond them. As a result, his distillation of modernist poetics to a few essential motifs could be seen as an historically conservative gesture. Of course, this judgment is complicated by the fact that the careers of the two writers overlap considerably: Beckett died in 1989 and wrote some of his most significant works toward the end of his life-that is, during the period in which Valente was writing his best work. One must be careful, then, not to draw too definitive a contrast between these two quintessential "late moderns."

Another significant difference between Valente and Beckett is that the Spanish poet's "negative theology" ultimately appears much more susceptible to positive recuperations. Where Beckett often seems to be parodying the mystical tradition, or reducing it to absurdity, Valente takes a more reverential attitude. This is not to say that he takes a straightforwardly religious or theistic approach to mystic texts, but neither does he rule out such approaches. His studies of San Juan de la Cruz, Miguel de Molinos, and other writers of the Spanish mystic tradition follow canons of scholarly scrupulousness and adopt a tone of high seriousness (see his Variaciones, for example). As we have seen, positive recuperations of Beckett's "mysticism" are not uncommon, but Valente's work is perhaps even more open to such recuperations, many of which adopt a specifically Heideggerian vocabulary. Cuesta Abad, for example, argues that Valente's mystic negation of ordinary referential language serves to make room for more authentically poetic uses of language (321-22).

\section{Valente and Late Modernism in Spain}

What, then, is Valente's place in literary history? More specifically, what does his example teach us about the reception of this Beckett-inspired late modernism in the Spanish context? The most obvious difference between Valente and his late modern precursors, of course, is that Valente writes after them. Valente is often celebrated for embodying the spirit of modernity in Spain, a nation supposedly recalcitrant to the sort of literary modernity represented by writers like Celan, Lezama Lima, and Beckett. His is not just a late modernism, but a late-late modernism, coming after and echoing the works of already canonical writers. There are a few problems, however, in over-emphasizing this belatedness. In the first place, the time lag between Valente and his principal late modernist influences is relatively short. Although Celan committed suicide in 1970, Beckett, as noted earlier, continued to produce significant work into the 1980s. Thus it would 
be more accurate to see Valente as writing at the tail end of a literary movement that stretches to the end of the twentieth century, if not beyond.

To emphasize Valente's lateness with respect to his European colleagues, furthermore, is to inscribe him in a narrative of Spanish cultural inferiority. Indeed, what we might call the "Subirats hypothesis" - the argument that the insufficiency or outright absence of the Spanish enlightenment is repeated yet again in the cultural and intellectual failure of the transition to democracy-is only the latest version of the master-narrative of failed Spanish modernity (Subirats, ed. Intransiciones). In fact, because narratives of failed or insufficient modernity have been relevant to the field of Hispanism at least since the invention of the concept of the "Generation of '98," it would be only a slight exaggeration to call this the central problematic of Hispanism itself. Practitioners of cultural studies, intellectual historians, philosophers, and literary critics have all contributed to discussions of this problem in recent years. Helen Graham and Jo Labanyi, for example, employ the phrase "the struggle for modernity" as a subtitle for their influential anthology Spanish Cultural Studies: An Introduction, implying that this struggle is in fact the major theme of this emergent field. Likewise, a conference held at the University of Illinois in 2003, and attended by many prominent hispanists, bore the symptomatic title "Recalcitrant Modernities: Spain, Difference, and the Construction of European Modernism."

Inherent to the narrative of insufficient modernity is the archetype of the heroic intellectual, the perpetual outsider who attempts to bring modernity to Spain, in the manner of José Blanco White, Mariano José Larra, Américo Castro, and Juan Goytisolo. Goytisolo, who was himself influential in creating this pantheon and forging this myth, in turn influenced younger intellectuals such as Subirats. There is also evidence that Valente, a friend and intellectual collaborator of Goytisolo, subscribed to a similar account of Spanish intellectual history, seeing himself as a "progressive outsider" in relation to Spanish culture. The positions he took in the 1980s and 1990s, in both politics and "literary politics," were close to those of Goytisolo, and both men viewed with disdain the official literary culture of this period. Thus, despite the central role each has played in defining Spanish literature in the second half of the twentieth century, neither has been elected to the Real Academia or awarded the Premio Cervantes. ${ }^{4}$

However, the figure of the intellectual outsider also carries with it some problematic implications that need to be considered. Such a figure will often seem prototypically "European" within the national context, the bearer of new ideas from abroad. At the same time, within the larger European context the same writer might appear less significant-both somewhat derivative of better known writers like Celan and Beckett and too preoccupied, perhaps, with the purely national question of Spain's insufficient Europeanness. An insistence on Valente's role as a European intellectual, then, has the paradoxical effect of diminishing rather than enhancing his stature by forcing a comparison with writers who have

\footnotetext{
${ }^{4}$ It is easy to exaggerate Valente's marginality, however. He did garner significant accolades during the 1980s and 1990s: Premio de la Crítica, Premio de la Fundación Pablo Iglesias, Premio Príncipe de las Asturias de las Letras, and Premio Nacional de Poesía (Rodríguez Fer 91). His final collection, Fragmentos de un libro futuro, won the Premio Nacional de Poesía after the poet's death.
} 
been far more influential on the world stage. The European role, in other words, is best played on the national stage, where an intellectual outsider such as Valente is unquestionably a dominant figure.

Even in Spain the view of Valente as a somewhat imitative writer is not uncommon. This problem is aggravated, probably, by Valente's numerous imitators, who present a late, late modernism at several removes from the original source. Younger Spanish poets who practice a "minimalist" or "essentialist" style heavily indebted to Valente might easily be seen as derivative twice over, even if they write accomplished poetry within the confines of this style. A poetry so stripped down to its "essential" elements also will tend to lack the range and historical import of the major late modernists. In short, since Beckett and Celan are already literary minimalists, they leave little room for even more extreme stylistic reductions. A related problem is that literary critics who write about Valente often lose critical distance by identifying themselves closely with the author's own positions. Even the most adept explicators of his work-Jacques Ancet and José Manuel Cuesta Abad, for example-often seem more interested in championing and re-articulating his poetics than in taking a balanced view of his place in literary history.

Spanish literary intellectuals such as Valente, then, often seem to suffer from a certain lack of synchronicity: they are "advanced" in the national context yet simultaneously "belated" with respect to European culture, or at least with respect to the idealized "European culture" to which Spain aspires. Not surprisingly, narratives of Spanish cultural deficiency sometimes produce problematically anachronistic readings, in which a key figure will seem to be re-enacting, for better or worse, a cultural problem characteristic of a previous epoch rather than participating in the culture of his or her own time. If Luis Cernuda was the high Romantic poet that Spain never had in the nineteenth century (Silver), then it is difficult to see him as a modern poet, a contemporary of Luis Buñuel, Pablo Picasso, and María Zambrano. ${ }^{5}$ Is Pedro Almodóvar simply the reincarnation of the conservative spirit of the nineteenth-century zarzuela, as one recent interpretation has it? (Lamas). Or does Almodóvar in fact make a distinctive contribution to contemporary Spanish culture, a contribution not reducible to the leyenda negra of failed modernity? ${ }^{6}$

While such outright anachronism is best avoided, it is still possible to see Valente

\footnotetext{
${ }^{5}$ Silver's argument is more complex and subtle than this, and I cannot do it justice here. My point is that his insistence that Cernuda's role in Spanish literary history is to make "restitution" for an insufficient romanticism condemns the poet to a kind of literary limbo rather than allowing him to emerge as a fully twentieth-century figure.

${ }^{6}$ Although Lamas's take on Almodóvar is well argued and almost convincing on its own terms, it is in my view symptomatic of the weakness attending the more ambitious claims of the "Subirats Hypothesis," in which virtually all cultural manifestations of the Spanish transition to democracy are read for signs of insufficiency and latent conservatism. While I am in sympathy with this hypothesis, I feel that it ultimately fails to make useful distinctions: the novels of Benet and Mendoza, the philosophy of Savater, the street culture of the movida, the cinema of Almodóvar-for Subirats (and his immediate disciples) such diverse cultural manifestations end up having more or less the same cultural import (Subirats, "Transición y espectáculo"). One need not have a naively triumphalist view of the Spanish transition to democracy to see a fatal tendency toward overgeneralization in such arguments.
} 
as somewhat out of step with his historical moment. He is not the modern poet Spain never had, but a somewhat younger late-modernist cousin of Beckett and Lezama Lima. Modernist Spanish poetry of the 1920s and 1930s is, of course, a cultural achievement of unquestionable value. What Valente brings back to Spain is not an out-of-date "high modernism" but a specifically late modernist sensibility at several removes from the spirit of Guillén, Lorca, Aleixandre, or Cernuda. In other words, since modernism was already "late" when Valente began to adapt it to the Spanish context, his modernizing function becomes inherently paradoxical: the modernism he represents is already crepuscular, at a terminal stage of its evolution and thus invested with connotations of anachronism, decadence, and weakness.

Valente's desire to stake out a position for himself in literary history also leads him, at times, to neglect or disparage the work of the majority of the modernist poets of the Spanish "Generation of 1927": if he had more fully acknowledged the powerful work of Lorca and Aleixandre, he might have been more modest about his own place in literary history. Admittedly, Valente has a philosophical depth missing from some of the secondary figures of the 1920s-for example, Rafael Alberti or Gerardo Diego. The later, more discursive work of poets like Guillén and Aleixandre might also appear to be weak when compared to his. At the same time, it is hard to put Valente in the same category as a truly epochal figure like Lorca or to see his work as more original than the early, surrealistinfluenced poetry of Aleixandre and Cernuda. Valente's tendency to single out Cernuda as his only worthy precursor among Spanish poets thus seems selfserving, especially in light of revisionist work that questions the depth of Cernuda's turn toward romanticism (Jiménez Heffernan).

These questions become even more complicated if we remember that belatedness is a defining characteristic of literary modernity from its earliest moments. In "Three Movements," William Butler Yeats expressed the sentiment that his own period, which we now call "high modernism," was already a dim reflection of an earlier, more vital literature:

\section{Shakespearean fish swam the sea, far away from land; Romantic fish swam in nets coming to the hand; \\ What are all those fish that lie gasping on the strand? (Yeats 240)}

Yeats's view is far from exceptional: Octavio Paz and Harold Bloom, most notoriously, have seen modern poetry as a somewhat weaker repetition of Romantic poetics. Needless to say, such narratives should be looked upon with a great deal of skepticism: modernism is also correctly associated with the forward-looking impulse of futurism and the avant-garde. As modernism grows older, however, narratives of decadence become more intuitively convincing, resonating with our contemporary sense of modernism as an old movement that refuses to die. It is difficult indeed to sustain the concept of an avant-garde when the most daring contemporary artists are, in some sense at least, repeating the avant-garde gestures of eighty or ninety years ago.

One paradoxical result of the increasing importance of belatedness to our definitions of modernism is that it makes modernism seem oddly resilient. Anachro- 
nistic and seemingly weak from its very inception, it nevertheless has survived repeated prophecies of its demise, demonstrating in the process that epochs of supposed belatedness and decadence can turn out to be paradoxically fertile. Since belatedness is itself a central poetic topos of poetic modernity, late modernists are even more "modern" than their original models. Belatedness becomes, ultimately, a hidden source of poetic power, a way to "sacar fuerzas de flaquezas" (make a weakness into a strength). Literary history bears out this conclusion: Shakespeare's insistence that he is inferior to poets of previous ages does not actually weaken his Sonnets or threaten their place in the canon. Likewise, Beckett's terminal modernism has become as canonical as Yeats's fin-de-siècle symbolism. ${ }^{7}$ Both Irish writers were Nobel Laureates. "Late modernism" remains powerful even in its exiguous, vulnerable state. Some of its power, in fact, derives from its ostensible negativity. The secondary literature on Beckett demonstrates how easy it is to recuperate negativity, to rewrite anti-humanist insights in humanist terms. With Valente, too, minimalist techniques like extreme brevity and the elimination of literary ornament often yield maximalist claims of significance.

Even if one accepts the continued power and viability of this late modernist vision, it seems an inescapable conclusion that modernism, once an inaugural and ambitious movement oriented toward the future, deliberately presents itself as moribund and residual rather than triumphantly inaugural. Modernism, in Beckett and Valente, is in its terminal stages, unable to move forward. Indeed, the images of decadence and death in the works of such writers are consonant with the imminent death of the modern movement itself. Perhaps modernism is already dead and can only be practiced in its negative modalities. What is especially striking, however, is how long this "terminal" stage of modernism has lasted: roughly from the late 1940s, when Beckett was writing Waiting for Godot and The Unnameable, to the death of Valente at the end of the millennium. Late modernism is endlessly dilated - an extreme terminal point stretched out to almost unbelievable lengths, like the liminal state between life and death of one of Beckett's fictional protagonists. Thus late modernism, in Beckett as in Valente, presents itself as a residual movement, neither dead nor vitally alive, at once prestigious and relatively marginal to the culture as a whole.

\section{Conclusion}

This essay has attempted to bring together two well-known and influential "master narratives." One is the well-known story of the "death of the avant-garde"represented here by the descent of literary modernism into the self-annulling negativity of the works of Samuel Beckett and José Angel Valente. The other is the national problematic of the Spanish "struggle for modernity," in which the

\footnotetext{
${ }^{7}$ I have deliberately avoided characterizing Valente's late modernism as a form of "postmodernism." Valente himself, to the best of my knowledge, never used the term, and I suspect he was hostile to the phenomenon itself as well as the word that designates it. He always identified strongly with classic manifestations of literary modernity rather than with the mixture of high and low art that characterized the original postmodernism of the late 1960s and early 1970s. He is, as I will suggest at the conclusion of this essay, a late modernist poet writing in a "postmodern" period.
} 
critical intellectual attempts to import modernity into a Spain recalcitrant to change. The obvious lesson here is that these two narratives are difficult to reconcile: a predominantly elegiac, residual modernism, however powerful it remains in literary terms, cannot easily perform the function of cultural regeneration in the national context; Beckett's late modernist paradigm, represented here by Valente, cannot bring cultural or historical "modernity" to Spain.

Needless to say, what we call "modernism" in literature has more often than not been out of step with the historical project of "modernity," if the latter is understood as the completion of the Enlightenment project of rationality. After all, literary modernism has its ultimate roots, not in the Enlightenment, but in the Romantic reaction to the nightmares of rationality. Modern literature is, more often than not, a deeply ambivalent counter-discourse ill at ease with any "progressive" model of historical development. Valente's affinities with Spanish mystics like Miguel de Molinos and San Juan de la Cruz, with Heidegger and Hölderlin, and with the pessimistic, crepuscular late-modernism of Celan and Beckett put him at some distance from any Enlightenment idea of historical progress. There would seem to be a gap, then, between Valente's role as a "progressive" intellectual and his commitment to a late modernist literature that questions the very notion of historical progress.

Valente himself notes the peculiar disjunction between historical events and artistic creation in the works of two major modernist writers:

En el diario de Kafka las líneas dedicadas a la primera guerra mundial no pasan de cincuenta. Pocas semanas después del comienzo de la guerra sus preocupaciones son la escritura de "La colonia penal" y el comienzo de El proceso.

Durante la guerra, Joyce está entregado a la escritura de la primera parte del Ulises.

El tiempo del escritor no es el tiempo de la historia. Aunque el escritor, como toda persona, pueda ser triturada por ella.

(Notas de un simulador 34 )

(In Kafka's diary the lines dedicated to the First World War are fewer than fifty. A few weeks after the onset of the war his preoccupations are the writing of "The Penal Colony" and the beginning of The Trial.

During the war, Joyce is engaged in writing the first part of Ulysses.

The time of the writer is not the time of history. Although the writer, like anyone else, can be ravaged by it.)

Valente is not quite proposing that writing should be considered outside of its historical moment, sub specie aeternitatis. After all, it would be difficult to think of a writer more relevant to twentieth-century history than Franz Kafka. The complex relationship between Kafka and his times, however, cannot be defined by looking directly at contemporaneous events. The connection, if there is one, is necessarily more oblique.

What, then, is the relation of Valente's late, late modernism to his own historical epoch? From one perspective, there is a lack of synchronicity: his residual modernism has little or no relevance to the issues troubling contemporary Spain. Yet this apparent anachronism is itself a sign of the times. I would argue that José Angel Valente is one of the paradigmatic poets of the transition to democracy in Spain, not because his poetic work reflects the historical events of this period, 
but because his problematic role as a late modernist exemplifies an underlying cultural problem: the insufficiency of Spanish "modernity" in a postmodern age.

University of Kansas

\section{Works Cited}

Beckett, Samuel. Collected Shorter Plays. New York: Grove Press, 1984.

The Complete Short Prose: 1929-1989. Ed. S.E. Gontarski. New York: Grove Press, 1995.

Nohow On. Ed. S.E. Gontarski. New York: Grove Press, 1996.

Proust. Three Dialogues. London: John Calder, 1965.

Cronin, Anthony. Samuel Beckett: The Last Modernist. New York: HarperCollins, 1997.

Cuesta Abad, José Manuel. Poesía y enigma. Madrid: Huerga \& Fierro, 1999.

Epps, Brad, and Luis Fernández Cifuentes, eds. Spain beyond Spain: Modernity, Literary History, and National Identity. Lewisburg: Bucknell University Press, 2005.

Graham, Helen, and Jo Labanyi, eds. Spanish Cultural Studies: An Introduction. The Struggle for Modernity. Oxford: Oxford University Press, 1995.

Jiménez Heffernan, Julián. "Ni experiencia de meditación: Cernuda por razones equivocadas." La Alegría de los Naufragios 7-8 (2003): 11-37.

Lamas, Rafael. "Zarzuela y restauración en el cine de Almodóvar." Subirats 53-60.

Lopo, María. "A lingua francesa na poesía de José Angel Valente.” Moenia 6 (2000): 41-49.

Mayhew, Jonathan. "Valente's Lectura de Paul Celan and the Heideggerian Tradition in Spain." Diacritics 34.3-4 (2004): 73-89.

Perloff, Marjorie. The Dance of the Intellect: Studies in Poetry of the Pound Tradition. Cambridge: Cambridge University Press, 1985.

Silver, Philip. Ruin and Restitution: Reinterpreting Romanticism in Spain. Nashville: Vanderbilt University Press, 1997.

Subirats, Eduardo, ed. Intransiciones: Crítica de la cultura española. Madrid: Biblioteca Nueva, 2002.

—_. "Transición y espectáculo." Subirats 71-85.

Valente, José Angel. Cantigas de alén. Santiago de Compostela: Consorcio de Santiago, 1996.

— Fragmentos de un libro futuro. Barcelona: Galaxia Gutenberg, Círculo de Lectores, 2000.

—. La experiencia abisal. Barcelona: Galaxia Gutenberg, 2004.

—. Las palabras de la tribu. Madrid: Siglo XXI, 1971.

—. Material memoria (1979-1989). Madrid: Alianza, 1992.

—. No amanece el cantor. Barcelona: Tusquets, 1992.

—. Notas de un simulador. Madrid: Ediciones La Palma, 1997.

—. Variaciones sobre el pájaro y la red. La piedra y el centro. Barcelona: Tusquets, 1991.

Williams, Raymond. Marxism and Literature. Oxford: Oxford University Press, 1977.

Wolosky, Shira. Language Mysticism: The Negative Way in Eliot, Beckett, and Celan. Stanford: Stanford University Press, 1995.

Yeats, William Butler. The Collected Poems of W.B. Yeats. Ed. Richard J. Finnerman. Rev. 2nd Ed. New York: Simon \& Schuster, 1996. 